analysis. Both wrote the paper. Caroline Ramazanoglu assisted at an early stage of the study, Kate Nash provided invaluable advice and support, and Floss Chittenden provided unfailing support with the transcriptions of the interviews. HL is guarantor.

Funding: None

Competing interests: None declared.

Ethical approval: The full relevant requirements for the ethical conduct of research, as set out by the British Sociology Association (www.britsoc.co.uk/Library/Ethicsguidelines2002.doc), were strictly adhered to.

1 Bloom SW. The medical school as a social organisation: the source of resistance to change. Med Educ 1989;23: 228-41.

2 General Medical Council Tomonois doctors: recommendations on undergraduate medical education. London: GMC, 1993

3 Hafferty FW, Franks R. The hidden curriculum, ethics teaching, and the structure of medical education. Acad Med 1994;69:861-71.

Hafferty FW. Beyond curriculum reform: confronting medicine's hidden curriculum. Acad Med 1998;73:403-7.

5 Sinclair S. Making doctors. An institutional apprenticeship. Oxford: Berg, 1997

6 Cribb A, Bignold S. Towards the reflexive medical school: the hidden curriculum and medical education research. Stud Higher Educ 1999;24: 195-209.

7 Hafferty FW. Reconfiguring the sociology of medical education: emerging topics and pressing issues. In: Bird F, Conrad P, Fremont AM, eds. Handbook of medical sociology, 5th ed. New York: Prentice Hall, eds. Handbook

Bloom SW. Innocence in education. School Rev 1972;80:333-59.

9 Assor A, Gordon D. The implicit learning theory of hidden curriculum research. J Curric Stud 1987;19:329-39.

10 Anderson DJ. The hidden curriculum. Am J Roent 1992;159:21-2.

11 Marinker M. Myth, paradox and the hidden curriculum. Med Educ 2001;31:293-8.

12 DeSchepper EJ. The hidden curriculum in dental education. J Dent Educ 1987:51:575-7.

13 Mayson J, Hayward W. Learning to be a nurse: the contribution of the hidden curriculum in the clinical setting. Nurse Pract N Z 1997;12:16-22

4 Helman C. The dissection room. In: Body Myths. London: Chatto and Windus, 1991:114-23.

15 Coldicott Y, Pope C, Roberts C. The ethics of intimate examinationsteaching tomorrow's doctors. BMJ 2003;326:97-101.

16 Wright S, Kern DE, Kolodner K, Howard DE, Brancati FL. Attributes of excellent attending-physician role models. $N$ Engl J Med 1998:339: 1986-93.

17 Lempp HK. Undergraduate medical education: a transition from medical student to pre-registration doctor [dissertation]. London: Goldsmiths College, University of London, 2004.

18 Seale C. The quality of qualitative research. Introducing qualitative methods. London: Sage, 1999: 119-39.

19 Savage J. What is happening to nursing? BMJ 1995;311:274-5
20 Seabrook MA. Medical teachers' concerns about the clinical teaching context. Med Educ 2003;37:213-22.

21 Dearing R. Summary report: the National Committee of Inquiry into Higher Education Norwich:HMSO, 1997.

22 General Medical Council. Tomorrow's doctors: recommendations on undergraduate medical education. London: GMC, 2002.

23 Leinster SJ. Medical education in the real world. Med Educ 2003;37:397-8.

24 Hicks B. How can a deanery win the battle against bullying? BMJ Careers 2003;326(suppl):S129. http://careerfocus.bmijournals.com/cgi/content/ full/326/7393/S129

\section{Corrections and clarifications}

Spinal immobilisation for unconscious patients with multiple injuries

One keystroke occluded the identity of the second author of this clinical review by $\mathrm{C} \mathrm{G}$ Morris and colleagues (28 August, pp 495-9), leading to Eamon Paul McCoy being listed as W McCoy. The correct designation of the authors is $\mathrm{C}$ G Morris, $\mathrm{E}$ P McCoy, G G Lavery. The bmj.com versions have been amended.

Lassa fever: epidemiology, clinical features, and social consequences

A further small error has belatedly come to light in this clinical review by J Kay Richmond and Deborah J Baglole (BMJ 2003;327:1271-5). Reference 12 should have read: Bausch D. Lassa fever in Sierra Leone. London: World Health Organization, 2000 (that is, not published by Merlin, as was stated).

Hospital at home for patients with acute exacerbations of chronic obstructive pulmonary disease: systematic review of evidence

The authors of this paper, Felix S F Ram and colleagues, point out that they should have said that a longer version of their review (7 August, pp 315-8) is available in the Cochrane Library (Ram FSF, Wedzicha JA, Wright J, Greenstone M. Hospital at home for acute exacerbations of chronic obstructive pulmonary disease. Cochrane Database Syst Rev 2004;(3):CD003573).

\title{
Testing hypotheses
}

Medicine is the natural home of the untested hypothesis, says Hugh Pennington while wondering why doctors are so unscientific. ${ }^{1}$ When the pain started to go down my left arm, one day some four years ago, I considered my family history of heart disease and came to the obvious conclusion. So the next day I cycled from University College London to the Royal Free Hospital, up Hampstead Hill, to my relief without a twinge. With the angina hypothesis disproved, I could safely ignore the pain, which was conveniently intermittent if unpredictable, and get on with a busy job.

Digging up a tree root changed everything. The pain worsened, but subsided with the cocktail of paracetamol and ibuprofen that I recommend to so many patients, so I could carry on hacking and heaving. Carrying heavy bags on a holiday journey further tested my second hypothesis-muscle sprain-and I was able to experience the peculiar apprehension that comes with being ill away from home. Then the escalating pain, interrupted sleep, and diminished power in the left arm demolished the muscle hypothesis and replaced it with a neurological one. A colleague in neurology diagnosed a cervical disc prolapse, confirmed by magnetic resonance imaging.

I was soon back on my bike, although I gave tree roots a wide berth, with just the occasional dart of pain and, more often, odd tingles in the hand or forearm. Thus, when the arm throbbed at the start of a tennis match just before Easter I put it down to the neck problem and carried on. The feeling disappeared, only to recur the next day as I was cycling up a relatively gentle incline, but it stopped when I reached level ground and did not recur when I cycled home. The dodgy disc hypothesis held, and I dug out some analgesia in case I needed it.

That night I could not sleep for the pain in my arm. Paracetamol did not touch the pain, and, as it spread across the chest and I began to feel nauseated, I finally realised that the disc was innocent. The emergency services moved quickly, and the hospital departments dealt with the incident with great skill. Undergoing an emergency coronary artery bypass graft is an education, particularly if you have no major risk factors for heart disease (the "family history" now being attributed to smoking rather than genetics).

Back on my bike again and even eyeing a tree root in need of extraction, I understand that medicine is the natural home of hypothesis testing, but that we do not test hypotheses under circumstances of our own choosing but according to our hopes, fears, and competing demands.

Steve Iliffe senior partner, Lonsdale Medical Centre, London (s.iliffe@pcps.ucl.ac.uk)

1 Pennington H. Why can't doctors be more scientific? London Review of Books 2004;26(13):28-9 